\title{
Lichen biota of tree fall disturbances in the Polish part of the Karkonosze Mts (West Sudety Mts)
}

\author{
Monika Staniaszek-Kik \& Katarzyna Szczepańska
}

\author{
Lichen biota of tree fall disturbances in the Polish part of the Karkonosze Mts (West Sudety \\ Mts). - Čas. Slez. Muz. Opava (A), 60: 139-146, 2011.
}

\begin{abstract}
The paper contains a list of 38 lichen species collected on tree fall disturbances (pitmound-root plate complexes) in the Polish part of the Karkonosze Mts. Seven of these species are threatened in Poland: Arthrorhaphis grisea, Bacidina arnoldiana, Cladonia bellidiflora, Lichenomphalina umbelifera, Porpidia cinereoatra, Psilolechia clavulifera, Trapeliopsis gelatinosa, and two are protected by Polish law: Parmeliopsis ambigua and Pseudevernia furfuracea. Root plates with uprooting pits and mounds create conditions for the development of lichens characterized by very different habitat requirements (photolichens, hygrolichens, skiolichens). Presence of these microhabitats in the forest communities is important for preserving diversity of lichens. Among pit-mound-root plate complex the best conditions for the development of lichen biota are on the root plates. Tree fall disturbances are important microhabitats for pioneer crustose lichens.

Key words: lichens, tree fall disturbances, Karkonosze Mts, Poland
\end{abstract}

\section{Introduction}

Since the mid-ninetheenth century Karkonosze Mountains present a very interesting object of scientific research. According to lichens the first data from this mountain range come from papers by German (Flotow 1849, 1850; Körber 1855, 1865; Stein 1879, 1889; Eitner 1896, 1901, 1911) and Czech (Kuták 1926, Suza 1928, 1929) scholars. During postwar years, when the Silesian part of Karkonosze Mts was joined to Poland, Polish lichenologists also joined to these studies (Tobolewski 1954; Fabiszewski 1978; Miądlikowska 1993; Kossowska 2002, 2003, 2008, 2009, 2010; Szczepańska and Szczepański 2006; Wawrecka and Kossowska 2006; Dimos-Zych and Czarnota 2007; Kossowska et al. 2007; Pietrzykowska and Kossowska 2010). As the result of all these investigations, in the Polish part of mountain range 600 lichen taxa have been found till now (Kossowska 2006). Despite many years of researches, lichen biota of Karkonosze Mountains is still only partially recognized.

Fallen trees with their roots are a steady and important component of forest communities. They affect not only the proper functioning of the forest ecosystems, but also help to create new niches, especially for spore organisms with small competitive abilities in relation to plants of dense undergrowth (Schaetzl et al. 1989a, b; Jonsson 1990; Jonsson and Esseen 1990; Schaetzl et al. 1990; Jonsson and Dynesius 1993; Holeksa 1998; Ulanova 2000; von Ohiemb et al. 2007; Pawlik 2009; Lõhmus et al. 2010). Despite the presence of uprooted trees in forest ecosystems is common, the studies of those microhabitats and organisms inhabiting them were rarely undertaken in Poland, including Karkonosze Mountains (Faliński 1976, 1978; Masalska 1994; Cieśliński et al. 1995; Klama 1995, 2002; Żarnowiec 1995a,b; Faliński et al. 1996; Zubel 2008; Staniaszek-Kik 2008; Żarnowiec and Staniaszek-Kik 2008, 2009a,b).

The aim of this study is to supplement the knowledge on lichens of Karkonosze Mountains. The study focuses on the lichen biota inhabiting tree fall disturbances (pit-moundroot plate complexes).

\section{Methods}

Field studies were conducted in 2003-2006 in the Polish part of Karkonosze Mountains. Due to the high accumulation of uprooted trees the most of the study was focused in forest areas being a part of the Karkonosze 
National Park. The occurrence of lichens was analyzed on three types of objects: root plates, uprooting pits and uprooting mounds. This study does not include lichens occurring on logs of uprooted trees as they are an object of a separate study. For each of objects the occurrence of lichen species was recorded on various types of substrates: soil, humus, small fragments of wood, stones and roots. During the study the lichens were examined on 268 objects, i.e. 115 root plates, 80 uprooting pits and 73 uprooting mounds.

In the laboratory standard methods of morphological, anatomical and chemotaxonomical analyses were used. For taxa in which the secondary chemistry is important for species determination (e.g. Lepraria spp.) the analysis of chemical composition was studied by thin layer chromatography (TLC) (Orange et al. 2001).

The threat categories are given after the "Red list of lichens in Poland" (Cieśliński et al. 2006). Legally protected species are distinguished according to the Decree of the Polish Minister of Environment (Dz. U. Nr 168, poz. 1765), while lichenes nomenclature was adopted according to the study by Smith et al. (2009), and for some taxa - by Diederich (2011) and Fałtynowicz (2003).

The lichens are listed in alphabetical order. For each species the following data are given: frequency (according to the scale: $1-10$ localities $=$ rare species, $11-20=$ frequent, and over $20=$ common), number of records, detailed information about the type of inhabited substrate, and list of localities.

\section{Results}

Thirty-eight lichen species were found as occurring on tree fall disturbances (pitmound-root plate complexes) in the area of Karkonosze Mountains during present study. This includes 32 species inhabiting root plates, 25 species noted around the uprooting mounds, and 14 species found in the uprooting pits.

Seven species of lichens endangered in Poland were recorded, including one in the category EN (Endangered: Cladonia bellidiflora (Ach.) Schaer.), one as VU (Vulnerable: Arthrorhaphis grisea Th.Fr.), four as NT (Near Threatened: Bacidina arnoldiana Körb., Lichenomphalina umbelifera (L.: Fr.) Redhead, Lutzoni, Moncalvo \& Vilgalys, Psilolechia clavulifera (Nyl.) Coppins, Trapeliopsis gelatinosa (Flörke) Coppins \& P. James) and one as LC (Least Concern: Porpidia cinereoatra (Ach.) Hertel \& Knoph). Two lichen species are protected in Poland (Parmeliopsis ambigua (Wulfen) Nyl., Pseudevernia furfuracea (L.) Zopf).

\section{ALPHABETIC LIST OF THE LICHEN SPECIES}

Arthrorhaphis grisea Th. Fr. - category VU, rare (1 record: root plate). 1 locality: Czarna Kopa Mt. 1247 m. $766 \mathrm{~m}$

Bacidina arnoldiana Körb. - category NT, rare (1 record: root plate). 1 locality: Karpacz-Wilcza Poręba

Baeomyces rufus (Huds.) Rebent. - common (59 records: root plates -25 , uprooting pits -15 , uprooting mounds - 19). 34 localities: Szrenica Mt. 1182 m; Łabski Szczyt Mt. 1118 m; Dolne Gawry rocks 689 m, 769 m; near Koralowa Ścieżka road 869 m; valley of Sopot stream 576 m, 650 m, 659 m, 669 m, 671 m, 696 m, 698 m, 710 m, 740 m, 766 m, 773 m, 776 m, 787 m, 811 m, 838 m; valley of Polski Potok stream 907 m; Chojnik Mt. 549 m; Turek Mt. 856 m; valley of Łomnica stream 922 m; Kopa Mt. 1080 m; Czarna Kopa Mt. 1093 m, 1211 m, 1215 m, 1247 m, 1270 m; Czarny Grzbiet ridge 1074 m, 1085 m, 1088 m; Dolina Łomniczki valley $1118 \mathrm{~m}$.

Cladonia bellidiflora (Ach.) Schaer. - category EN, rare (1 record: uprooting mound). 1 locality: Łabski Szczyt Mt. $1114 \mathrm{~m}$.

Cladonia chlorophaea (Flörke ex Sommerf.) Spreng. - rare (2 records: uprooting mounds). 2 localities: Czarna Kopa Mt. 1256 m; Czarny Grzbiet ridge 1088 m.

Cladonia coniocraea (Flörke) Spreng. - rare (1 record: root plate). 1 locality: Łabski Szczyt Mt. 1124 m.

Cladonia digitata (L.) Hoffm. - frequent (31 records: root plates - 24, uprooting mounds - 7). 20 localities: Przedział Mt. 977 m, 1042 m; Szrenica Mt. 1140 m, 1172 m; Łabski Szczyt Mt. 1075 m, 1114 m, 1118 m; Kopa Mt. 1080 m, 1196 m; Czarna Kopa Mt. 1080 m, 1122 m, 1243 m, 1247 m, 1256 m, 1258 m; Czarny Grzbiet ridge 1083 m, 1088 m; Dolina Łomniczki valley 783 m, 877 m, 1118 m.

Cladonia fimbriata (L.) Fr. - rare (1 record: root plate). 1 locality: Kopa Mt. 1199 m.

Cladonia ochrochlora Flörke - frequent (22 records: root plates - 16, uprooting pits -1 , uprooting mounds - 5). 16 localities: Szrenica Mt. 1140 m; Łabski Szczyt Mt. 1075 m, 1114 m, 1204 m; Dolne Gawry rocks 689 m, 745 m, 809 m; near Koralowa Ścieżka road 865 m; Czeskie Kamienie Mt. 1130 m; Chojnik Mt. 549 m; Kopa Mt. 1080 m, 1198 m; Czarna Kopa Mt. 1256 m, 1258 m; Czarny Grzbiet ridge 1088 m; Skalny Stół Mt. $1261 \mathrm{~m}$. 
Cladonia polydactyla (Flörke) Spreng. - rare (2 records: root plates - 1, uprooting mounds - 1). 2 localities: Szrenicki Potok valley 682 m; Kopa Mt. 1208 m.

Cladonia pyxidata (L.) Hoffm. - rare (3 records: root plates). 3 localities: Szrenica Mt. 1172 m; Łabski Szczyt Mt. 1124 m; Czarna Kopa Mt. 1256 m.

Hypocenomyce scalaris (Ach. ex Lilj.) M. Choisy - rare (3 records: root plates). 3 localities: Przedział Mt. 1042 m; valley of Łomnica stream 1105 m; Kopa Mt. 1196 m.

Hypogymnia physodes (L.) Nyl. - rare (10 records: root plates). 9 localities: Szrenica Mt. 1140 m; Czeskie Kamienie Mt. 1089 m; valley of Łomnica stream 1105 m; Kopa Mt. 1196 m; Czarna Kopa Mt. 1080 m, 1250 m; Czarny Grzbiet ridge 1144 m; Dolina Lomniczki valley 783 m, 1118 m.

Lecanora conizaeoides Nyl. - frequent (24 records: root plates - 21, uprooting pits - 2, uprooting mounds - 1). 21 localities: Szrenica Mt. 1140 m; Dolne Gawry rocks 689 m, 745 m, 758 m, 769 m, 780 m, 809 m; near Koralowa Ścieżka road 865 m; valley of Sopot stream 650 m, 771 m, 811 m, 838 m; valley of Polski Potok stream 907 m; Chojnik Mt. 543 m, 572 m; valley of Łomnica stream 1105 m; Kopa Mt. 1196 m; Czarny Grzbiet ridge 1088 m, 1144 m; Dolina Łomniczki valley 783 m, 1118 m.

Lecidea pullata (Norman) Th. Fr. - rare (8 records: root plates -7 , uprooting mounds -1 ). 5 localities: Szrenica Mt. 1140 m; Łabski Szczyt Mt. 1075 m, Czeskie Kamienie Mt. 1089 m, Kopa Mt. 1207 m; Czarna Kopa Mt. 1256 m.

Lepraria elobata Tønsberg - rare (11 records: root plates -8 , uprooting pits - 1, uprooting mounds - 2). 8 localities: Łabski Szczyt Mt. 1114 m, 1204 m; Dolne Gawry rocks 689 m; Czeskie Kamienie Mt. 1134 m; Kopa Mt. 1196 m; Czarna Kopa Mt. 1101 m, 1250 m; Czarny Grzbiet ridge 1088 m.

Lepraria jackii Tønsberg - frequent (26 records: root plates -21 , uprooting pits -1 , uprooting mounds 4). 20 localities: Przedział Mt. 977 m, 1042 m; Szrenica Mt. 1140 m, 1182 m; Labski Szczyt Mt. 1114 m; Dolne Gawry rocks 745 m; Śmielec 1074 m; near Koralowa Ścieżka road 865 m; Czeskie Kamienie Mt. 1089 m; Turek Mt. 856 m; Kopa Mt. 1080 m, 1196 m; Czarna Kopa Mt. 1093 m, 1239 m, 1243 m, 1250 m; Dolina Łomniczki valley 783 m, 891 m,1118 m; Karpacz-Wilcza Poręba town 789 m.

Lepraria toensbergiana Bayerová \& Kukwa - rare (4 records: root plates). 4 localities: Przedział Mt. 977 m; Czeskie Kamienie Mt. 1089 m; Dolina Łomniczki valley 834 m, 877 m.

Lichenomphalina umbelifera (L.: Fr.) Redhead, Lutzoni, Moncalvo \& Vilgalys - category NT, rare (2 records: root plates -1 , uprooting mounds - 1). 2 localities: Czarny Grzbiet ridge 1088 m; Dolina Łomniczki valley $877 \mathrm{~m}$.

Micarea botryoides (Nyl.) Coppins - common (33 records: root plates - 27, uprooting pits - 1, uprooting mounds - 5). 27 localities: Przedział Mt. 1042 m; Szrenica Mt. 1182 m; Łabski Szczyt Mt. 1075 m, 1114 m, 1118 m, 1204 m; Dolne Gawry rocks 689 m, 780 m, 809 m; Śmielec 1068 m; near Koralowa Ścieżka road 865 m; Czeskie Kamienie Mt. 1089 m, 1134 m; valley of Sopot stream 810 m; Długi Grzbiet ridge 929 m; valley of Łomnica stream 1105 m; Kopa Mt. 1196 m; Czarna Kopa Mt. 1028 m, 1080 m, 1211 m, 1247 m; Czarny Grzbiet ridge 1088 m, 1144 m; Dolina Łomniczki valley 783 m, 877 m; Sowia Dolina valley 855 m; Skalny Stół Mt. $1046 \mathrm{~m}$.

Micarea peliocarpa (Anzi) Coppins \& R. Sant. - frequent (18 records: root plates - 14, uprooting pits 1, uprooting mounds - 3). 14 localities: Dolne Gawry rocks 758 m, 768 m, 809 m; valley of Sopot stream 650 m, 698 m, 710 m, 771 m, 773 m, 780 m, 807 m, 811 m, 838 m; Czarna Kopa Mt. 1211 m; Dolina Łomniczki valley $783 \mathrm{~m}$.

Micarea prasina Fr. s.1. - common (17 records: root plates - 16, uprooting mounds - 1). 17 localities: Dolne Gawry rocks 768 m, 769 m, 780 m, 809 m; near Koralowa Ścieżka road 865 m; Czeskie Kamienie Mt. 1089 m; valley of Sopot stream 675 m, 807 m; Długi Grzbiet ridge 929 m; valley of Łomnica stream 1105 m; Czarna Kopa Mt. 1080 m, 1256 m; Dolina Łomniczki valley 783 m, 834 m, 887 m; Sowia Dolina valley 863 m; Skalny Stół Mt. 1046 m.

Parmeliopsis ambigua (Wulfen) Nyl. - protected species, rare (2 records: root plates). 2 localities: Czarna Kopa Mt. 1247 m; Dolina Łomniczki valley 1118 m.

Placynthiella dasaea (Stirt.) Tønsberg - common (66 records: root plates - 48, uprooting pits - 4, uprooting mounds - 14). 47 localities: Przedział Mt. 977 m, 1042 m; Szrenica Mt. 1182 m; Łabski Szczyt Mt. 1114 m, 1204 m; Dolne Gawry rocks 689 m, 758 m, 768 m, 769 m, 780 m, 809 m; Śmielec Mt. 1088 m, 1110 m; near Koralowa Ścieżka road 865 m, 869 m, 851 m; valley of Wrzosówka stream 926 m; Czeskie Kamienie Mt. 1089 m, 1134 m; valley of Sopot stream 650 m, 675 m, 683 m, 771 m, 780 m, 807 m, 838 m; valley of Polski Potok stream 940 m; Długi Grzbiet ridge 929 m; Chojnik Mt. 572 m; Turek Mt. 856 m; valley of Łomnica stream 922 m, 1105; Kopa Mt. 1196 m; Czarna Kopa Mt. 1028 m, 1080 m, 1101 m, 1122 m, 1243 m, 1241 m, 1250 m, 1264 m; Czarny Grzbiet ridge 1085 m, 1088 m, 1144 m; Dolina Łomniczki valley 783 m; Sowia Dolina valley 863 m; Skalny Stół Mt. 1046 m.

Placynthiella icmalea (Ach.) Coppins \& P. James - rare (10 records: root plates). 10 localities: Przedział Mt. 1042 m; Łabski Szczyt Mt. 1075 m, 1118 m; Dolne Gawry rocks 769 m, 791 m; Śmielec Mt. 1068 m; Czarna Kopa Mt. 1080 m, 1256 m; Sowia Dolina valley 855 m; Skalny Stół Mt. 1046 m. 
Placynthiella uliginosa (Schrad.) Coppins \& P. James - rare (4 records: root plates - 3, uprooting mounds - 1). 4 localities: Przedział Mt. 977 m; Łabski Szczyt Mt. 1114 m; Kopa Mt. 1080 m; Dolina Łomniczki valley $877 \mathrm{~m}$.

Porpidia cinereoatra (Ach.) Hertel \& Knoph - category LC, rare (1 record: uprooting mound). 1 locality: Czarny Grzbiet ridge 1088 m.

Porpidia crustulata (Ach.) Hertel \& Knoph - rare (1 record: uprooting pit). 1 locality: Czarna Kopa Mt. $1250 \mathrm{~m}$.

Pseudevernia furfuracea (L.) Zopf - protected species, rare (4 records: root plates - 1, uprooting pits 1, uprooting mounds - 2). 2 localities: Szrenica Mt. $1140 \mathrm{~m}$; valley of Sopot stream 786 m. $1140 \mathrm{~m}$.

Psilolechia clavulifera (Nyl.) Coppins - category NT, rare (1 record: root plate). 1 locality: Szrenica Mt.

Thelocarpon lichenicola (Fuckel) Poelt \& Hafellner - rare (2 records: root plates -1 , uprooting pits -1$)$. 1 locality: Czarna Kopa Mt. $1211 \mathrm{~m}$.

Trapelia coarctata (Turner ex Sm.) M. Choisy - rare (6 records: root plates -1 , uprooting pits -1 , uprooting mounds - 4). 3 localities: valley of Sopot stream 698 m, 710 m, 785 m.

Trapelia corticola Coppins \& P. James - rare (2 records: uprooting pits - 1, uprooting mounds -1$)$. 2 localities: Czarna Kopa Mt. 1093 m; Czarny Grzbiet ridge 1083 m.

Trapelia glebulosa (Sm.) J.R. Laundon - rare (2 records: root plates - 1, uprooting pits - 1). 2 localities: valley of Sopot stream 740 m; Czarna Kopa Mt. 1270 m.

Trapeliopsis flexuosa (Fr.) Coppins \& P. James - frequent (29 records: root plates - 23, uprooting pits 2, uprooting mounds - 4). 18 localities: Szrenica Mt. 1172 m; Łabski Szczyt Mt. 1204 m; valley of Szrenicki Potok stream 640 m; Dolne Gawry rocks 689 m, 745 m, 768 m; near Koralowa Ścieżka road 851 m; valley of Sopot stream 650 m, 710 m, 789 m, 807 m, 838 m; valley of Polski Potok stream 907 m; Długi Grzbiet ridge 929 m; Kopa Mt. 1199 m; Czarna Kopa Mt. 1256 m; Czarny Grzbiet ridge 1088 m; Dolina Łomniczki valley 783 m.

Trapeliopsis gelatinosa (Flörke) Coppins \& P. James - category NT, common (32 records: root plates 19, uprooting pit - 1, uprooting mounds - 12). 26 localities: Przedział Mt. 977 m; Szrenica Mt. 1140 m; Łabski Szczyt Mt. 1075 m, 1114 m; Dolne Gawry rocks 689 m, 769 m; valley of Wrzosówka stream 926 m; Czeskie Kamienie Mt. 1130 m; valley of Sopot stream 576 m, 680 m, 696 m, 710 m, 807 m, 838 m; valley of Polski Potok stream 907 m; Chojnik Mt. 543 m; valley of Łomnica stream 922 m, 1105 m; Kopa Mt. 1196 m; Czarna Kopa Mt. 1093 m, 1211 m, 1250 m; Czarny Grzbiet ridge 1065 m, 1144 m; Dolina Łomniczki valley 783 m, $1118 \mathrm{~m}$.

Trapeliopsis granulosa (Hoffm.) Lumbsch - rare (12 records: root plates - 10, uprooting mounds - 2). 10 localities: Łabski Szczyt Mt. 1114 m, 1124 m; Dolne Gawry rocks 689 m; Śmielec Mt. 1088 m; near Koralowa Ścieżka road 851 m, 865 m; Kopa Mt. 1199 m, 1208 m; Czarna Kopa Mt. 1258 m; Czarny Grzbiet ridge $1088 \mathrm{~m}$

Trapeliopsis pseudogranulosa Coppins \& P. James - frequent (18 records: root plates - 8, uprooting pits - 1, uprooting mounds - 9). 17 localities: Szrenicki Potok valley 640 m; Dolne Gawry rocks 780 m; valley of Sopot stream 592 m, 687 m, 689 m, 696 m, 698 m, 771 m, 786 m, 807 m, 811 m; Chojnik Mt. 489 m; Czarna Kopa Mt. 1101 m, 1211 m; Czarny Grzbiet ridge 1088 m; Dolina Łomniczki valley 877 m; Sowia Dolina valley $855 \mathrm{~m}$.

\section{Discussion}

Thirty-eight lichen species were found on studied uprooted trees in the forests of the Karkonosze Mountains, which represent $6 \%$ of lichen biota of this area (Kossowska 2006). In the analyzed biota taxa which were classified as "rare" (1-10 localities) clearly predominated (55\% of all recorded species). The group of "frequent" species (11-20 localities) included $34 \%$ of recorded taxa, while ,common" species (over 20 localities) grouped only $10 \%$ of noted lichenes. The most frequently noted species were: Baeomyces rufus, Micarea botryoides, Placynthiella dasaea and Trapeliopsis gelatinosa.

Uprooted trees cause a lot of changes in the forest environment. One of the effects is the creation of distinctive land microsculpture in the form of uprooted pits and mounds and exposed root plate (Jonsson and Essen 1990; Scheatzl et al. 1990; Faliński et al. 1996; von Oheimb et al. 2007; Pawlik 2009). Each of these forms becomes a microhabitat characterized by specific conditions and is a potential place for the occurrence of lichens (Jonsson and Essen 1990; Faliński et al. 1996; Ulanova 2000; Lõhmus et al. 2010). Root plates are elevated above the ground surface and vertical blocks of soil together with the roots of fallen trees (Gutowski et al. 2004; Pawlik 2009). The specificity of this microhabitat is the high 
availability of light, but also a huge overdrying (Masalska 1994; Faliński et al. 1996). On root plates was recorded $91 \%$ of all lichen biota noted in the studied tree falls disturbances and the most often recorded species are: Baeomyces rufus, Cladonia digitata, Lecanora conizaeoides, Lepraria jackii, Micarea botryoides, Placynthiella dasaea and Trapeliopsis flexuosa. Comparing to other types of studied objects, on the root plates lichens characterized by slightly higher light requirements (photolichens), as well as species preferring wood or bark of trees as a substrate, may grow up. Such taxa colonize fragments of withered roots These characters can explain occurrence of Bacidina arnoldiana, Hypocenomyce scalaris, Hypogymnia physodes and Parmeliopsis ambigua in the studied area.

Uprooted pits (space arose in place where raised root plates have occurred) form a microhabitat with the very small access to light and with a periodic stagnant rainwater and snowmelt (Masalska 1994; Żarnowiec 1995; Faliński et al. 1996). Therefore, it is the most suitable habitat for species that tolerate or even prefer a high moisture content (hygrolichens) and a little sunshine (skiolichens), e.g. Baeomyces rufus, Micarea peliocarpa, Trapelia glebulosa and Trapeliopsis gelatinosa. Ecological conditions in the uprooting pits are not conducive to the development of lichen biota. In this type of microhabitat the presence of lichens was found only in $30 \%$ of all surveyed objects and the its species list groups only $37 \%$ of all lichen biota noted in the studied pit-mound-root plate complexes. Lack of lichens is often caused by the accumulation of a thick layer of organic matter. Frequently noticed lichen in the area of uprooting pits is the Baeomyces rufus. Other species have been recorded only in single localities.

Uprooting mounds are formed of soil, sand and organic matter crumbling from the root plate (Scheatzl et al. 1989b; Pawlik 2009). They are less moist, but also have a lower reactivity than intact soil (Masalska 1994; Gutkowski et al. 2004). The most frequently species in this microhabitat are: Baeomyces rufus, Micarea botryoides, Placynthiella dasaea, Trapeliopsis gelatinosa, Trapeliopsis pseudogranulosa and also epigeic Cladonia species. Sixty five percent of lichen species were found on the analyzed uprooted mounds on tree fall disturbances in the studied area.

Root plates, as well as pits and mounds, are characterized by large variation of substrates, and consists of pieces of rocks and stones, wood and bark, roots (exposed along with the crunching soil), but mainly bare ground. Within the tree fall disturbances the mineral soil is the dominant type of substrate, hence epigeic species, such as Cladonia ssp., Placynthiella uliginosa, Trapeliopsis granulosa and T. gelatinosa are the commonest in that type of microhabitat. An equally large proportion of lichens are associated with bark and wood. Typically epilitic taxa, e.g. Porpidia cinereoatra, P. crustulata, Trapelia coarctata or T. glebulosa, were the rarest among noted lichen species and occurred only in single positions. Generally they were associated with small fragments of rocky substrata.

Uprooted trees during their existence are still subjected to quite fast and substantial changes. The material forming the root plates spills slowly and is rinsed out by precipitation, while uprooting mound is simultaneously destroyed and formed. This gives rise to the endless movement of organic matter and fragments of rocks (Schaetzl et al. 1989b; Ulanova 2000). Therefore pit-mound-root plate complexes create favorable conditions for the development of pioneering species, so called ephemerolichens. In terms of morphological forms the species with crustose $(68 \%)$ and fruticose $(21 \%)$ thalli predominate in the analyzed lichen biota. A large percentage of crustose species in studied biota can be explained by the fact that in this group many taxa show a high capacity for rapid colonization of newly formed substrates (Lipnicki 1998; Cieśliński 2003).

Uprooting trees are important elements in forest communities. Unfortunately from the forest management point of view they are often undesirable in forests, and foresters always try to reduce the risk of their formation. As a result uprooting trees are quickly removed from 
forest areas. When their logs are cutted off the roots and taken away, very often the root plates return to their previous horizontal positions. Limiting the number of these specific microhabitats may consequently lead to the impoverishment of the local biodiversity of lichen biota.

\section{Conclusions}

1. Root plates with uprooting pits and mounds create conditions for the development of lichens of very different habitat requirements, and that is why their presence in the forest communities is important for preserving species diversity of this group of organisms.

2. Tree fall disturbances (pit-mound-root plate complexes) are important microhabitats for pioneer crustose lichens.

3. Within the tree fall disturbances the best conditions for the development of lichen biota are on the root plates and on uprooting mounds.

Acknowledgements: We are grateful to Dr hab. Paweł Czarnota for revising our identifications of some Micarea species and Dr Martin Kukwa for determining species from Lepraria genus by thin layer chromatography. We wish to thank Dr Radomir Jaskuła for checking the English.

\section{References}

Cieśliński S. (2003): Atlas rozmieszczenia porostów (Lichenes) w Polsce północno-wschodniej. Phytocoenosis 15(N.S.), Supplementum Cartographiae Geobotanicae 15, Warszawa-Białowieża, 30 pp.

Cieśliński S., Czyżewska K. \& Glanc K. (1995): Lichenes. - In Faliński J.B. \& Mułenko W. (eds): Cryptogamous Plants in the Forest Communites of Białowieża National Park. - Phytocoenosis 7 (N.S.). Archivum Geobotanicum, 4: 75-86.

Cieśliński S., Czyżewska K. \& Fabiszewski J. (2006): Red list of the lichens in Poland. - In Mirek Z., Zarzycki K., Wojewoda W. \& Szeląg Z. (eds): Red list of plants and fungi in Poland. W. Szafer Institute of Botany, Polish Academy of Sciences, Kraków, pp. 71-91.

Diederich P., Ertz D., Stapper N., Sérusiaux E., Van den Broeck D., van den Boom P. \& Ries. C. (2011): The lichens and lichenicolous fungi of Belgium, Luxembourg and northern France. http://www.lichenology.info

Dimos-Zych M. \& Czarnota P. (2007): Porosty Doliny Łomniczki i Kotła Łomniczki we wschodniej części Karkonoszy. - In Štursa J. \& Knapik R. (eds): Geoekologické problémy Krkonoš. Sborník Mezinárodní Vědecké Konference, řijen 2006, Svoboda n. Úpou. - Opera Corcontica, 44(1): 289-304.

Dz. U. Nr 168, poz. 1765, 9 lipiec 2004. Rozporządzenie Ministra Środowiska z dnia 9 lipca 2004 r. w sprawie gatunków dziko występujących grzybów objętych ochroną.

Eitner E. (1896): Nachträge zur Flechtenflora Schlesiens. - Jahresbericht der Schlesischen Gesellschaft für Vaterländische Kultur, 73: 2-26.

- (1901): II Nachtrag zur Schlesischen Flechtenflora. - Jahresbericht der Schlesischen Gesellschaft für Vaterländische Kultur, 78: 5-27.

- (1911): Dritten Nachtrag zur Schlesischen Flechtenflora. - Jahresbericht der Schlesischen Gesellschaft für Vaterländische Kultur, 88(1): 20-60.

Fabiszewski J. (1978): Boulder fields on Wielki Szyszak. - In Wojterski T. (ed.): Guide to the Polish International Excursion 1978, Adam Mickiewicz University Poznań, Ser. Biologia, 11: 186.

Faliński J.B. (1976): Windwüre als Faktor der Differenzierung und der Veränderung des Urwaldbiotopes im Licht der Forschungen auf Dauerflächen. - Phytocenosis, Biuletyn Fitosocjologiczny, 5 (2): 85-108.

- (1978): Uprooted trees, their distribution and influence in the primeval forest biotope-- Vegetatio, 38: 175-183.

Faliński J.B., Mułenko W., Żarnowiec J., Klama H., Głowacki Z. \& Załuski T. (1996): The colonisation of fallen tree sites by green plants and fungi. - In Faliński J.B. \& Mułenko W. (eds): Cryptogamous plants in the forest communities of Białowieża National Park. - Phytocoenosis, 8 (N.S.). Archivum Geobotanicum 6: 147-150.

Fałtynowicz W. (2003): Lichens, lichenicolous and allied fungi of Poland. An annotated checklist. - W. Szafer Institute of Botany, Polish Academy of Sciences, Kraków, 435 pp.

Flotow J. (1849): Lichenes Florae Silesiae I. - Jahresbericht der Schlesischen Gesellschaft für Vaterländische Kultur, 27: 98-135.

- (1850): Lichenes Florae Silesiae II. - Jahresbericht der Schlesischen Gesellschaft für Vaterländische Kultur, 28: $115-143$.

Gutowski J. M. (ed.), Bobiec A., Pawlaczyk P. \& Zub K. (2004): Drugie życie drzewa. WWF Polska. Warszawa - Hajnówka, 245 pp. 
Holeksa J. (1998): Rozpad drzewostanu i odnowienia świerka a struktura i dynamika karpackiego boru górnoreglowego. - Monographiae Botanicae, 82: 1-208.

Jonsson B.G. (1990): Treefall disturbance - a factor structuring vegetation in boreal spruce forests. - In Krahulec F., Agnew A.D.Q., Agnew S. \& Willems J.H. (eds): Spatial processes in plant communities. p. 89-98. SBP Academic Publisher. The Hague.

Jonsson B.G. \& Essen P.-A. (1990): Treefall disturbance maintains high bryophyte diversity in boreal spruce forest. - Journal of Ecology, 78: 924-93.

Jonsson B.G. \& Dynesius M. (1993): Uprooting in boreal spruce forests: long-term variation in disturbance rate. - Canadian Journal of Forest Research, 23: 2383-2388.

Klama H. (1995): Hepaticopsida. - In Faliński J.B. \& Mułenko W. (eds): Cryptogamous Plants in the Forest Communites of Białowieża National Park. - Phytocoenosis 7 (N.S.). Archivum Geobotanicum, 4: 6374.

- (2002): Distribution patterns of liverworts (Marchantiopsida) in natural forest communities (Białowieża Primeval Forest, NE Poland). University of Bielsko-Biała, Bielsko-Biała, pp. XIV+278.

Körber G. W. (1855): Systema lichenum Germaniae (I-XXXIV). Die Flechten Deutschlands mikroskopisch geprüft, kritisch gesichtet, charakteristisch beschreiben und systematisch geordnet. - Verlag von Trewendt und Granier, Breslau.

- (1865): Parerga lichenologica. Erganzungen zum Systema Lichenum Germaniae. - Verlag E. Trewendt, Breslau.

Kossowska M. (2002): Ostoja rzadkich porostów epifitycznych na jodłach w Wąwozie Szklarki (Karkonoski Park Narodowy). - Przyroda Sudetów Záchodních, 5: 85-92 .

- (2003): Lichens growing on silver fir (Abies alba) in the Karkonosze National Park (SW Poland) - the result of the first stage of the conservation programme. - Botanica Lithuanica, 9: 65-70.

- (2006): Checklist of lichens and allied fungi of the Polish Karkonosze Mts. - Instytut Botaniki im. W. Szafera PAN, Kraków, 131 pp.

- (2008): New and interesting lichenicolous fungi of the Karkonosze Mountains, SW Poland. - Herzogia, 21: 229-232.

- (2009): Materiały do rozmieszczenia porostów naskalnych w Karkonoszach. I. Grunty strukturalne Czarnego Grzbietu. - Acta Botanica Silesiaca, 4: 161-169.

- (2010): Materiały do rozmieszczenia porostów naskalnych w Karkonoszach. II. Skałki rejonu Szrenicy. - Acta Botanica Silesiaca, 5: 157-166.

Kossowska M., Szczepańska K., Fałtynowicz W., Jando K., Kowalewska A. \& Dimos M. (2007): Różnorodność gatunkowa porostów epifitycznych na stałych powierzchniach monitoringowych w Karkonoskim Parku Narodowym. - Parki Narodowe i Rezerwaty Przyrody, 26(1): 3-16.

Kuták V. (1926): Přispěvek k lichenologii Krkonoš. - Preslia, 4: 20-29.

Lipnicki L. (1998): Kształtowanie się flor porostów na podłożach o cechach pionierskich. - Monographiae Botanicae, 84: 1-21.

Lõhmus P., Turja K. \& Lõhmus A. (2010): Lichen communities on treefall mounds depend more on rootplate than stand characteristics. - Forest Ecology and Management, 260: 1754-1761.

Masalska A. (1994): Na straży puszczańskich ostępów ... - Parki Narodowe, 3: 3-5.

Miądlikowska J. (1993): Porosty epifityczne jako wskaźniki degradacji środowiska w Karkonoskim Parku Narodowym. - Parki Narodowe i Rezerwaty Przyrody, 12(1): 27-38.

Orange A., James P. W. \& White F. J. (2001): Microchemical methods for the identification of lichens. British Lichen Society, London.

Pawlik Ł. (2009): Znaczenie saltacji wykrotowej w kształtowaniu rzeźby stoku. - Czasopismo Geograficzne, 80(3): 130-146.

Pietrzykowska K. \& Kossowska M. (2010): Porosty antropogenicznych podłoży wapiennych wokół schronisk górskich w polskiej części Karkonoszy. - Fragmenta Floristica et Geobotanica - Series Polonica, 17(1): 141-147.

Schaetzl R.J., Burns S.F., Johnson D.L. \& Small T.W. (1989a): Tree uprooting: review of impact on forest ecology. - Vegetatio, 79: 165-176.

Schaetzl R.J., Johnson D.L., Burns S.F. \& Small T.W. (1989b): Tree uprooting: review of terminology, process, and environmental implications. - Canadian Journal of Forest Research, 19: 1-11.

Schaetzl R.J., Burns S.F., Small T.W. \& Johnson D.L. (1990): Tree uprooting: review of types and patterns of soil disturbance. - Physical Geography, 11(3): 277-291.

Smith C.W., Aptroot A., Coppins B.J., Fletcher A., Gilbert O.L., James P.W. \& Wolseley P.A. (2009): The lichen of Great Britain and Ireland. British Lichen Society, London, 1046 pp.

Staniaszek-Kik M. (2008): Wzorce rozmieszczenia wybranych grup fototrofów na murszejącym drewnie i wykrociskach w zbiorowiskach leśnych Karkonoszy. - Zakład Bioróżnorodności i Ochrony Szaty Roślinnej, Instytut Biologii Roślin, Uniwersytet Wrocławski, Wrocław. Ph.D. thesis, 449 pp. 
Stein B. (1879): Flechten. In Cohn's Kryptogamenflora von Schlesiens. - Jahresbericht der Schlesischen Gesellschaft für Vaterländische Kultur, 2(2): 1-400.

- (1889): Nachträge zur Flechtenflora Schlesien. - Jahresbericht der Schlesischen Gesellschaft für Vaterländische Kultur, 66: 142-149.

Suza J. (1928): Nové lišejniky Krkonoš. - Věda Př́rodní, 9: 305-309.

- (1929): Srovnávací a poznámky k zeměpisnému rozšíření lišejníků na Sudetách, zvláště východních. I. Sborník Klubu Přirod., Brno, 11: 128-155.

Szczepańska K. \& Szczepański A. (2006): Porosty z rodzaju Bryoria w Karkonoszach. - Fragmenta Floristica et Geobotanica - Series Polonica, 13(1): 191-195.

Tobolewski Z. (1954): Lichenotheca Polonica. Fasc. V. Lichenes Sudetici (Karkonosze). - Wydawnictwo PAN, Poznań.

Ulanova N.G. (2000): The effects of windthrow on forests at different spatial scales: a review. - Forest Ecology and Management, 135: 155-167.

von Oheimb G., Friedel A., Bertsch A. \& Härdtle W. (2007): The effects of windthrow on plant species richness in a Central European beech forest. - Plant Ecology, 191: 47-65.

Wawrecka K., Kossowska M. (2006): Porosty epifityczne, epigeiczne i epiksyliczne Sowiej Doliny we wschodniej części Karkonoszy. - Przyroda Sudetów, 9: 71-80.

Zubel R. (2008): Habitat offer for bryophytes in the natural fir forest, Abietetum polonicum (Roztocze National Park, SE Poland): preliminary quantitative analysis, pp. 205-209. In Kočárek P., Plášek V, Malachová K. \& Cimalová Š. (eds): Environmental changes and Biological Assessment IV. Scripta Facultatis Naturalium Universitatis Ostraviensis 186, Ostrava, 391 pp.

Żarnowiec J. (1995a): Mchy wykrotów w lasach naturalnych niżowej Polski. - In Mirek Z. \& Wójcicki J.J. (eds), Szata roślinna Polski w procesie przemian. Materiały konferencji i sympozjów 50 Zjazdu Polskiego Towarzystwa Botanicznego Kraków 26.06-01.07.1995, Kraków, p. 487.

- (1995b): Bryopsida. - In Faliński J.B. \& Mułenko W. (eds): Cryptogamous Plants in the Forest Communities of Białowieża National Park. - Phytocoenosis 7 (N.S.). Archivum Geobotanicum, 4: 47-61.

Żarnowiec J. \& Staniaszek-Kik M. (2008): Distribution patterns of bryophyte and lichen species richness and diversity in subalpine Norway spruce forests in the Karkonosze Mts (Sudeten, SW Poland), pp. 21-217. In Kočárek P., Plášek V, Malachová K. \& Cimalová Š. (eds): Environmental changes and Biological Assessment IV. Scripta Facultatis Naturalium Universitatis Ostraviensis 186, Ostrava, 391 pp.

- (2009a): Wzorce rozmieszczenia bogactwa oraz różnorodności gatunkowej porostów i mszaków w Dentario enneaphyllidis-Fagetum na górze Chojnik (Karkonoski Park Narodowy). Ochrona Środowiska i Zasobów Naturalnych, 38: 407-416.

- (2009b): Lichens and plants inhabiting snags in mountain forests of the Karkonosze National Park (Sudetes Mts, SW Poland). - Nowellia bryologica 2009 numéro spécial: 78-90.

\section{Summary}

The study area was situated in a Polish part of the Karkonosze Mts, the Western Sudetes (SW Poland). Field data were collected in the years 2003-2006. This paper contains the results of studies on lichens appearing on tree fall disturbances (pit-mound-root plate complexes). Overall, a total of 115 root plates, 80 mounds and 73 pits were examined. Thirty-eight species of lichens have been recorded, including: 32 species noted on root plates, 25 on mounds and 14 on pits. The most frequent species were: Baeomyces rufus, Micarea botryoides, Placynthiella dasaea, and Trapeliopsis gelatinosa. Seven of recorded species are threatened in Poland (Arthrorhaphis grisea, Bacidia arnoldiana, Cladonia bellidiflora, Lichenomphalina umbelifera, Porpidia cinereoatra, Psilolechia clavulifera, Trapeliopsis gelatinosa) and two are protected by Polish law: Parmeliopsis ambigua and Pseudevernia furfuracea.

The following data are given for each species: frequency, number of records, habitat preferences and altitude.

Authors' addresses: Monika Staniaszek-Kik, Department of Geobotany and Plant Ecology, University of Łódź, Banacha 12/16, PL-90-237 Łódź, Poland; e-mail: kik@biol.uni.lodz.pl Katarzyna Szczepańska, Department of Botany and Plant Ecology, Wroclaw University of Environmental and Life Sciences, pl. Grunwaldzki 24a, PL-50-363 Wrocław, Poland; e-mail: siemuszka@wp.pl 